\title{
Mapping displaced populations with reference to social vulnerabilities for post-disaster public health management
}

\author{
Junaid Ahmad, ${ }^{1}$ Anees Ahmad, ${ }^{2}$ Mokbul Morshed Ahmad, ${ }^{3}$ Nafees Ahmad \\ ${ }^{1}$ Department of Disaster Preparedness, Mitigation and Management, Asian Institute of Technology, \\ Pathumthani, Thailand; ' ${ }^{2}$ Department of Space Science, Institute of Space Technology, Islamabad, Pakistan; \\ ${ }^{3}$ School of Environment, Resources and Development, Asian Institute of Technology, Pathumthani, \\ Thailand; ${ }^{4}$ Department of Development Studies, Pakistan Institute of Development Economics, Islamabad, \\ Pakistan
}

\begin{abstract}
Millions of people are currently displaced from their homes because of local and international conflicts. In the last two decades, a substantial increase in the number of displaced people has been recorded. We measured the social vulnerabilities of displaced populations using a mathematical approach in combination with application of geographical information systems (GIS) tools
\end{abstract}

Correspondence: Junaid Ahmad, Department of Disaster Preparedness, Mitigation, and Management, Asian Institute of Technology, 12120 Pathumthani, Thailand.

E-mail: junaid.ahmad@ait.asia

Key words: Disaster planning; Vulnerable populations; Population surveillance; GIS; Pakistan.

Acknowledgments: the primary author is thankful to the Higher Education Commission of Pakistan for funding the author's doctoral study. We are also grateful to the Government of Khyber Pakhtunkhwa, Pakistan, and the Directorate General Health Services for allowing us to access the complete District Health Information System database.

Contributions: JA and AA conceived and designed the study. JA and NA collected the field data and did the data analysis. AA did the GIS mapping and write-up. MMA contributed to the critical review of the paper for quality and write-up.

Conflict of interest: the authors declare no potential conflict of interest. The funding sponsors had no role in the design of the study; in the collection, analyses, or interpretation of the data; in the writing of the manuscript; and in the decision to publish the results.

Received for publication: 9 April 2017.

Revision received: 28 September 2017.

Accepted for publication: 28 September 2017.

(C) Copyright J. Ahmad et al., 2017

Licensee PAGEPress, Italy

Geospatial Health 2017; 12:576

doi:10.4081/gh.2017.576

This article is distributed under the terms of the Creative Commons Attribution Noncommercial License (CC BY-NC 4.0) which permits any noncommercial use, distribution, and reproduction in any medium, provided the original author(s) and source are credited. and techniques to visualise movement and draw attention to the location of significant concentration of vulnerabilities. A retrospective study approach based on datasets collected from governmental and non-governmental organisations working with refugees and internally displaced persons in Pakistan was used. We applied simple mathematical formulas to calculate and map various types of vulnerability, such as refugee population, absorption capacity, unmet needs and overall vulnerability. This approach displays risks and vulnerabilities of displaced populations in an easily understood and straightforward manner that can be replicated in other parts of the world.

\section{Introduction}

Hundreds of active conflicts engross a large part of the world at present (Schultz, 2017). The most prominent of these involve Arabic countries, including Syria, Iraq, Yemen and Libya (Byman and Speakman, 2016) together with Afghanistan and Pakistan (Taylor, 2016). As a result, millions of people have lost their lives, and many have been forced to migrate from their homes and communities (Taylor, 2016). According to recent estimates by the United Nations High Commissioner for Refugees (UNHCR), about 6.5 million people are currently displaced, either as refugees (people forced to leave their country) or as internally displaced persons (IDPs). The number of refugees in the world is at the highest level since the Second World War (UNHCR, 1992, 2015) with the majority coming from Syria and Afghanistan (Donini et al., 2016). The two countries currently hosting the greatest numbers of refugees are Turkey with 2.5 million and Pakistan with 4.5 million (UNHCR, 2015).

The United Nations Office for Disaster Risk Reduction (UNISDR) emphasises that displacement in itself is a driver of future disaster risks, and it places people at a higher risk of impoverishment and human rights violations while exacerbating any pre-existing vulnerability (UNISDR, 2013). Wherever homes and livelihoods are destroyed, and where it is recurrent or unresolved, serious political differences for prolonged periods, displacement follows. Forced from their homes, people face heightened protection risks with regard to family separation, as well as sexual and gender-based violence, which particularly affect women and children (Cernea, 1999). People displaced by disasters are thus among the most vulnerable populations (Cutter et al., 2003) whose only option to avoid even worse situations is to leave their homes to seek a new life (Vecere et al., 2017). This most often leads to 
dependence on external assistance; thus in the long-term displaced persons are the ones most affected by disasters.

Public health analyses of refugee and IDP populations entail the study of the number, distribution, movement, age structure, birth and death rates of a particular group of people, i.e. those forced to live in camps. Overcrowding affects health both physically and mentally, undermining resistance and increasing the risk of contracting infections. Malnutrition is another constant and subtle threat leading to individuals being more prone to diseases; they often fall sick and, in the case of pregnant women, child mortality increases. People living in refugee camps also receive inadequate medical service, either due to inaccessibility, high price or lack of needed supplies making them vulnerable to disease (Haysom and el Sarraj, 2013). Certain groups of the study population (i.e. displaced people in camps) are the most vulnerable. These groups include children aged less than five years, childbearing mothers and people with increased risk of contracting disease and other adverse health conditions.

After the beginning of the Soviet war in Afghanistan in 1979, an estimated 5 million Afghan refugees fled to neighbouring Pakistan, a developing country with limited resources to accommodate this influx (Iram and Butt, 2004; Kronenfeld, 2008). There is now a disparity between different parts of the country, with most of the refugees and IDPs hosted in the least developed provinces, e.g., Khyber-Pakhtunkhwa (Shahbaz, 2013; Ahmad et al., 2017). In 2014 alone, Pakistan hosted approximately 1.6 million Afghan refugees (UNHCR, 2015), most of them residing in urban areas and refugee villages.

After more than thirty years of conflict, many Afghans have been born in Pakistan and assimilated into Pakistani communities (Kronenfeld, 2008). The unorganised exodus and return of refugees from and to Afghanistan makes it difficult to accurately characterise the population of refugees. Out of 1.6 million registered Afghan refugees, 1.01 million (63\%) live in urban and rural areas, while 0.59 million $(37 \%)$ are in 76 refugee villages in Khyber Pakhtunkhwa, Baluchistan and Punjab (UNHCR, 2015). Khyber-Pakhtunkhwa Province alone has received millions of refugees and IDPs fleeing areas of conflict stressing resources and capacity of this province beyond its limits. At present (August 2017), in addition to 1.6 million Afghan refugees, KhyberPakhtunkhwa accommodates more than 1 million IDPs from North Waziristan Agency, a mountainous region of north-western
Pakistan bordering Afghanistan (UNHCR, 2015). The refugee population has given rise to enormous pressure on service delivery related to health, education, livelihood and governance in general.

Disasters have historically been quantified with regard to direct loss of life and the capital stock depleted following the occurrence of natural events (Patankar and Patwardhan, 2016) or war. However, there is now a greater focus on the secondary effects of disasters that comes closer to capturing the critical component of livelihood in the disaster risk equation (Lim, 2016). The magnitude of displacement is related to the extent and frequency of extreme and non-extreme natural events (de Almeida, et al., 2016). The total number of people displaced by such events, both in relative and absolute terms, provides an important quantitative measure of their underlying vulnerability (Adeagbo et al., 2016). The distance of displacement, whether to another part of the same community or to a different country, is also an important factor contributing to the level of vulnerability and lack of resilience affecting affected communities (Bonanno et al., 2010).

Due to the Afghan war, which went on for over three decades, Pakistan remained at the top of the list of countries hosting the highest number of refugees until 2014, when it was surpassed by Turkey due to the Syria crisis (UNHCR, 2015). According to the Internal Displacement Monitoring Center (IDMC) (http://www.internal-displacement.org/internal-displacement/), Pakistan has not only been host to the largest number of refugees, but also of the highest number of IDPs for the last few years (IDMC, 2014). These population displacements have resulted in long-term social, political and economic consequences (Nomura et al., 2016). With a vulnerability score of 22 and a resilience score of 3.66, Pakistan ranks $2^{\text {nd }}$ in South Asia's Disaster Displacement Risk Index (DDRI) (Ginnetti et al., 2015). The DDRI, developed by the IDMC, predicts annual displacement for each country and each prevailing hazard type every year for the next ten years. The index assumes a scenario of business as usual and takes into account the actual intensity and frequency of the hazards of the past, as well as population growth and change in exposure and vulnerability with current rate (Ginnetti et al., 2015). An overview for Pakistan in this respect is presented in Tables 1 and 2.

As is common practice around the world, the Pakistani Government allocates resources based on population size. We discovered that budgets for the various fundamental needs are generally allocated without taking the actual refugee population into

Table 1. Pakistan's future annual displacement risk (next 10 years) (Ginnetti et al., 2015).

\begin{tabular}{lcccc} 
Population (n) & $\begin{array}{c}\text { Average risk of annual } \\
\text { displacement }\end{array}$ & $\begin{array}{c}\text { Regional rank } \\
\text { in risk of annual } \\
\text { displacement }\end{array}$ & $\begin{array}{c}\text { Relative annual } \\
\text { displacement } \\
\text { (per million) }\end{array}$ & $\begin{array}{c}\text { Regional rank } \\
\text { Change }\end{array}$ \\
\hline $187,250,400$ & $1,805,600$ & 2 & 9,600 & 3 \\
\hline
\end{tabular}

Table 2. Pakistan's displacement risk profile (Ginnetti et al., 2015).

\begin{tabular}{|c|c|c|c|c|c|}
\hline \multirow{2}{*}{$\begin{array}{l}\text { Relative physical } \\
\text { exposure }\end{array}$} & \multicolumn{3}{|c|}{ Risk configuration index } & \multicolumn{2}{|c|}{ Historic displacement } \\
\hline & Vulnerability & Resilience & $\begin{array}{c}\text { Risk } \\
\text { configuration }\end{array}$ & $\begin{array}{l}\text { Average annual } \\
\text { displacement } 2013 \text { - } \\
\text { trend level* }\end{array}$ & $\begin{array}{l}\text { Relative annual } \\
\text { displacement } \\
\text { (per million) } \\
2013 \text { - trend level* }\end{array}$ \\
\hline 95,112 & 22 & 3.6 & 0.58 & $1,566,000$ & 8,400 \\
\hline
\end{tabular}

*Trend level here means calculating the displacement estimates based on estimated past displacement using the best available disaster-loss data and calibrating it using the five best years of high-confidence estimates recorded in International Displacement Monitoring Centre's Disaster-induced Displacement Database (DiDD) (Ginnetti et al., 2015). 
account since refugees and IDPs are not properly captured by census statistics and documentation is often out of date. The last census was conducted in 1998 and with respect to KhyberPakhtunkhwa, displaced people were dispersed all over the province in the subsequent years. This means that refugees in districts with high refugee/host-community population ratios are in a particularly vulnerable situation. We propose a simple, innovative approach based on geographical information systems (GIS) visualising the magnitude and severity of these concerns and communicating the needs to public health professionals so that appropriate resources can be allocated according to the level of vulnerability in the target populations.

\section{Materials and Methods}

Although there are refugees in other Pakistani provinces, Khyber Pakhtunkhwa has the highest number of registered refugees, which made us choose this province for study. More specifically, we chose camps and refugee villages with a population of 5,000 or more refugees and IDPs, which are recognised by UNHCR and the Pakistani Government. We focused on camps with the highest populations and on those that have experienced a large influx of displaced populations in the past. Khyber Pakhtunkhwa Province currently hosts a total of 97 refugee/IDP camps, all of which are situated in 14 out of its 26 districts. The highest number of displaced people is in the district of Peshawar with 140,136 registered, displaced people (UNHCR, 2015) and the second highest is in the district of Haripur with 116,514.

\section{Study site}

Khyber Pakhtunkhwa is a province in north-western Pakistan comprising 26 districts. It is situated between latitudes $31^{\circ} 15^{\prime}$ and $36^{\circ} 57^{\prime}$ North and longitudes $69^{\circ} 5^{\prime}$ ' and $74^{\circ} 7^{\prime}$ 'East and located at the intersection of three mountain ranges: Himalaya, Hindukush, and Karakorum. Kashmir is to its Northeast and Punjab to its Southeast with Afghanistan and Federally Administered Tribal Areas (FATA) to its West; Afghanistan also borders the province in the North. The district of Peshawar has the highest population and harbours the provincial capital.

\section{Data sources}

The data, covering the period January 2012-December 2014 and related to refugee populations in Khyber Pakhtunkhwa, used in this study were provided by the organisations working with refugee/IDP camps in 14 districts: Peshawar, Nowshehra, Mardan, Haripur, Buner, Kohat, Dir, Mansehra, Swabi, Hangu, DI Khan, Chitral, Charsaddha and Lakki-Marwat. Many local and international organisations work with IDPs and refugees, but for reliability and authenticity, only data emanating from Commissionerate Afghan Refugees Khyber Pakhtunkhwa (KP) (http://kpkcar.org/ carnewsite/CAR/) and Frontier Primary Health Care (FPHC) (http://www.unhcr.org/partners/ngodirectory/48fdec0928/frontierprimary-health-care.html). The study is thus based on secondary, retrospective datasets. The use of secondary data (according to Sorensen et al. (1996) defined as information not collected with a specific research purpose) in public health and epidemiological research is currently increasing (Boslaugh, 2007).

According to these data, the total registered refugee population in Khyber Pakhtunkhwa is about 0.75 million. However, due to population movement and government policies that often shift populations from one place to another, the numbers vary over time. To reach an actual picture of our study population, data from the three study years (2012-2014) were included and an average obtained. Accordingly, our calculations are based on an average of 741,013 people residing within the camps in Khyber-Pakhtunkhwa Province at the time of the study.

The population in the camps had a ratio of $50.2 \%$ males and $49.8 \%$ females, similar to that of the host communities. To attain a structure of the study population based on age, we divided the population into three classes: infants up to 1 year of age $(3.9 \%$ of the total population, with roughly as many males as females); children aged $1-4(13.39 \%$ of the total population, with $6.7 \%$ males and $6.6 \%$ females) and those older than 5, which included $82.6 \%$ of the study population $(41.5 \%$ males and $41.1 \%$ females $)$ as shown in Table 3 .

Table 3. The study population: demographic profile 2012-2014.

\begin{tabular}{|c|c|c|c|c|c|}
\hline & & 2012 & 2013 & 2014 & Average \\
\hline $\begin{array}{l}\text { Total } \\
\qquad \text { Males } \\
\text { Females }\end{array}$ & & $\begin{array}{l}752,899 \\
375,384 \\
(49.9 \%) \\
372,083 \\
(50.2 \%)\end{array}$ & $\begin{array}{l}728,618 \\
366,568 \\
(50.3 \%) \\
362,050 \\
(49.7 \%)\end{array}$ & $\begin{array}{l}741,523 \\
373,947 \\
(50.4 \%) \\
367,576 \\
(49.7 \%)\end{array}$ & $\begin{array}{c}741,013 \\
50.2 \% \\
49.8 \%\end{array}$ \\
\hline $0-1$ years & Male & $\begin{array}{c}15,688 \\
(2.08 \%)\end{array}$ & $\begin{array}{c}14,478 \\
(1.98 \%)\end{array}$ & $\begin{array}{c}13,784 \\
(1.85 \%)\end{array}$ & $2.0 \%$ \\
\hline $0-1$ years & Female & $\begin{array}{l}15,242 \\
(2.0 \%)\end{array}$ & $\begin{array}{l}14,063 \\
(1.9 \%)\end{array}$ & $\begin{array}{l}13,531 \\
(1.8 \%)\end{array}$ & $1.9 \%$ \\
\hline$>1-4$ years & Male & $\begin{array}{l}50,045 \\
(6.6 \%)\end{array}$ & $\begin{array}{l}49,045 \\
(6.7 \%)\end{array}$ & $\begin{array}{l}50,753 \\
(6.8 \%)\end{array}$ & $6.7 \%$ \\
\hline$>1-4$ years & Female & $\begin{array}{l}49,057 \\
(6.5 \%)\end{array}$ & $\begin{array}{l}47,683 \\
(6.5 \%)\end{array}$ & $\begin{array}{l}49,215 \\
(6.6 \%)\end{array}$ & $6.6 \%$ \\
\hline$\geq 5$ years & Male & $\begin{array}{l}309,914 \\
(41.2 \%)\end{array}$ & $\begin{array}{l}303,046 \\
(41.6 \%)\end{array}$ & $\begin{array}{l}309,419 \\
(41.7 \%)\end{array}$ & $41.5 \%$ \\
\hline$\geq 5$ years & Female & $\begin{array}{l}308,486 \\
(41.0 \%)\end{array}$ & $\begin{array}{l}300,304 \\
(41.2 \%)\end{array}$ & $\begin{array}{l}304,827 \\
(41.1 \%)\end{array}$ & $41.1 \%$ \\
\hline
\end{tabular}




\section{Mapping}

To generate a map of the study area, the GIS data set for this research was downloaded from two websites (http://pakresponse. info/, and http://www.diva-gis.org/) and processed in QGIS 2.16 open source software (http://qgis.org/api/). GIS makes it possible to prepare separate layers for each attribute dataset and thus allows display of layers representing different information separately or together (Sadia et al., 2016). The descriptive data included the refugee camps including the name of the districts, numbers of host population, numbers of refugee population, numbers of refugee families, etc. The spatial data for Pakhtunkhwa Province included the longitude and latitude of the districts, topographic layers and the districts referred to by national administrative divisions. After compiling the datasets for each study period, we entered this information into the QGIS and built the layers needed adding North direction and legends.

\section{Classification}

We classified the study population according to gender and age because these variables are associated with different needs (WijkSijbesma, 2016). For example, children require vaccinations to prevent certain diseases, schools for learning and family support for psycho-social health; pregnant women need proper antenatal and postnatal care to prevent mortality and morbidity; married couples need family planning, counselling and information regarding contraception (Sedgh et al., 2016); while elderly people must have regular medication for diseases such as diabetes and hypertension.

\section{Definitions}

Displaced population (DP): The total number of displaced people settled in a district when from there from their home district, province or country.

Local population (LPV): The total number of people living in their home district.

Highest district displaced population (HDDP): the district that accommodates the highest number of displaced population among all 14 districts.

Displaced population families (DPF): The total number of displaced families settled in a district when moved there into a district from their home district, province or country.

While a family may consist of a large variation with regard to the number of members, it constitutes a single unit for some aid purposes. For example, in any emergency or humanitarian situation, assistance is typically provided based on family units, e.g., one tent for one family, while the number of individuals in the family becomes relevant with regard to the distribution of other aid items such as food and certain non-food items (NFIs), i.e., blankets, sleeping mats and plastic sheeting to safeguard them from harsh weather and other environmental conditions (IASC, 2007). To account for these different needs, we propose two different definitions of vulnerability: Unmet needs vulnerabilities (UNV) for intervention on a family-unit basis and absorption capacity vulnerability (ACV) for interventions on an individual basis. Taking these issues into consideration along with relative refugee vulnerability (RRV), we calculated the coefficient for four factors that influence the vulnerability of displaced population and host communities using the following formulas:

$\mathrm{RRV}=\mathrm{DP} / \mathrm{HDDP}$

Formula 1
$\mathrm{ACV}=\mathrm{DP} / \mathrm{LPV}$

Formula 2

$\mathrm{UNV}=\mathrm{DPF} / \mathrm{HDDP}$

Formula 3

In addition to these three formulas, a fourth formula defining the total vulnerability (TV) corresponding to the unweighted average, can be expressed as follows:

TV=Unweighted average of all three vulnerabilities Formula 4

According to IASC (2007) NFIs are divided into three broad categories to assist population displaced by any natural or manmade disasters. As there is always sacristy of resources during the time of emergency, conflict or disaster, development practitioners and planners need to prioritise their actions for supplying food items and NFIs to the most needed areas first. The Formulas 1 and 2 are proposed to help make such decisions of prioritisation.

A posting by Price (2017) entitled Opinion: see the most vulnerable - see the human landscape states Understanding the extent and specifics of humanitarian need is often a significant unknown. The current food security and IDP crisis in South Sudan underscores the importance of using remote sensing approaches to know exactly where vulnerable populations are migrating, how many displaced persons are on the move, what sort of resources they have access to and what threats and/or risks are nearby. A comprehensive foundational data set is incredibly valuable for intervention planning, but also critical to feasible exit strategies. In this regard, in order to allow policy-makers to better understand the amount of support needed in each area settled by refugees or IDPs, we propose using Formula 3.

\section{Results}

The calculated refugee population vulnerability at the district level is shown in Figure 1. This type of vulnerability mapping is proposed for strategies, e.g., based on the water, sanitation and hygiene (WASH) approach as well as for educational and health services. It is common practice that schools and hospital in a community are established based on the number of people residing in that community. Due to the unforeseen influx of displaced people from other districts only a limited number of these outsiders can be accommodated. This type of vulnerability will communicate the level of assistance needed in areas hosting displaced populations. Figure 1 clearly conveys the importance of calculating the impact of this vulnerability. In addition, general developmental practitioners and policymaker may not consider the district of Peshawar as particularly vulnerable because it is the capital city with a main hospital as well as many other healthcare institutions, both private and public. However, as we calculated the real vulnerability impact, we came to know that it is the most vulnerable district of the whole province due to an unforeseen influx of refugees. This may be because many refugees prefer to stay in urban area as there are more economic opportunities there compared to the rural situation. Figure 1 makes this clear in the shortest possible time and if available during the planning stage, maps of this kind would not only get the attention of decision-makers, but should also facilitate effective planning.

The calculated ACV (Figure 2) is proposed to express the extent of human resource shortage in the refugee affected and hosting areas (RAHA). For example, the number of doctors or the 


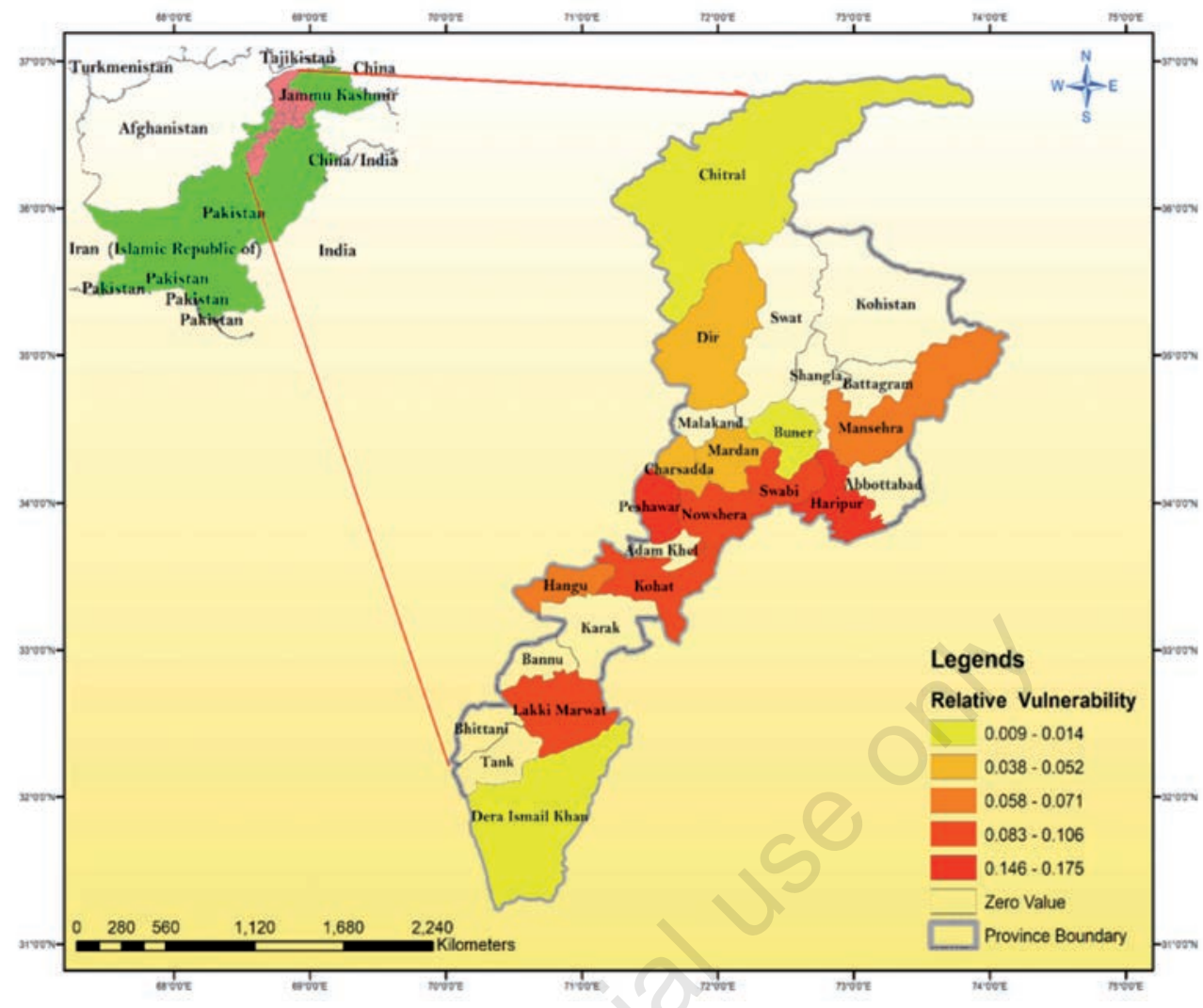

Figure 1. Calculated refugee population vulnerability at the district level.

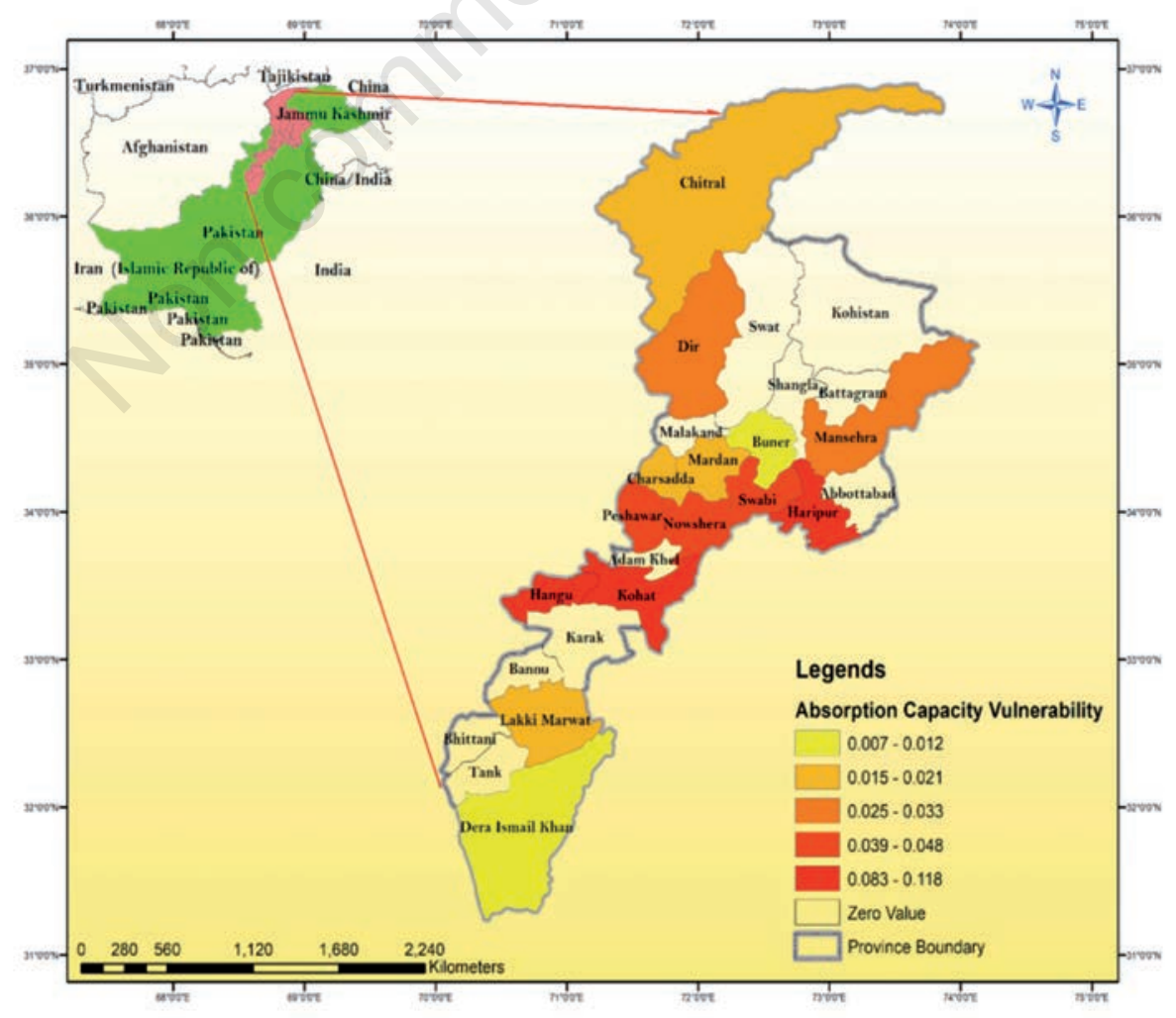

Figure 2. Calculated absorption capacity vulnerability at the district level. 
number of nurses is placed in a community according to the population number. In the case of Pakistan, especially in the present study area, the numbers are far lower than critical shortage of 1.7 health worker per 10,000 population suggested by WHO. This map approach communicates in a straightforward manner that Dera, Ismail, Khan and Chitral are the most remote districts and difficult to reach because of the geography. Interestingly, however, they appear to be comparatively less vulnerable because the ratio of refugee population to host population in these districts is better compared to more developed, easily accessible districts. The calculated ACV, visualised in Figure 2, is of high importance as it shows where the need is the greatest, i.e., not necessarily the rural areas with limited resources, but instead often urban areas that cannot accommodate overflows of refugees in spite better infrastructure and capacity (Sabates-Wheeler et al., 2008).

The UNV can be used to plan more efficient distribution of humanitarian assistance. We calculated this measure for 14 districts in our study area, and found that the values obtained communicated a different picture than other types of vulnerability. As seen in Figure 3, the districts with the greatest UNV values were LakkiMarwat and Peshawar.

After calculating the above-stated vulnerabilities, we also calculated the TV (Figure 4), which can be regarded as holistic as it takes into account all the different vulnerabilities. This is a useful measure proposed to apply when a complete picture of the whole province, country or region, is needed. All calculations discussed above are presented in Table 4 . The coefficients obtained are normalised to fall in the range from 0 to 1 .

\section{Discussion}

With respect to key problems such as the prevalence of malnutrition, high incidence of communicable diseases and the high mortality rate in the refugee camps, high-quality, extensive research is needed to understand the aetiology and impact of these issues in the context of war and disasters. Different monitoring tools and techniques need to be developed not only to assess the prevalence of malnutrition and other problems in this context, but also to measure the effectiveness and effect of possible interventions. In response to the need for full coverage by healthcare services, it is necessary for governmental and non-governmental organisations (NGOs) as well as international organisation to relocate health manpower and other material resources to the areas where camps for the displaced populations are, particularly in areas severely affected by complex humanitarian emergencies. This would help to sustain the non-material and health advantages which have been obtained by the host communities. Furthermore, it is essential to restructure the governmental health service system to make it more supportive for displaced people and geared to the attainment of health for all, particularly for those who are the most vulnerable, i.e., children and women.

Mapping of parameters, such as the extent of damage caused by a particular disaster, the level of floods, areas vulnerable to landslides, damaged road networks in disaster-struck areas, etc., are frequently reported by researchers and practitioners (Alphen and Aerts, 2009). This study proposes the novel approach of GIS mapping to efficiently visualise and disseminate information about refugees and internally displaced people in camps to government departments and relief organisations. These straightforward tools and techniques facilitate rapid decisions by emergency policy- makers and aid workers regarding the extent of resources required and in how to allocate them. It is also an efficient way to provide information to donors and decision-makers in the immediate aftermath of a disaster and in disaster preparedness planning. The mapping techniques with respect to social vulnerabilities proposed in this study should help by providing up-to-date information in a simple and efficient way leading to deployment of limited resources that can address the prevailing humanitarian situation in the most efficient way.

We derived the base and nomenclature of the vulnerabilities from previous studies (Weathers et al., 2004; Shi and Stevens, 2005; Cutter et al., 2008; Greenough et al., 2008). Weather et al. (2004) assessed the UNVs of migratory agriculture worker's children, and defined this vulnerability as the lack of ability to access health care which includes, but is not limited to, use of hospitals, ability to obtain medication, and antenatal and postnatal care. In this study, we not only assessed UNVs from a public health perspective but also visualised them using GIS. Shi and Stevens (2005) conclude in their study that there is a strong association between low socioeconomic status and lack of access to care by minorities and they recommended further development of more practical models to account for the clustering of multiple risks. In this respect, we feel that our study is a step forward.

When a country or province (as in this case) is flooded with refugees, international communities and the government of the host country prepare to send certain amounts of relief materials and logistical support to the affected areas. Mannella et al. (2017) analysed the need for population assistance during the reconstruction process after the 2009 L'Aquila earthquake, and calculated the number of people who required accommodation. However, these authors only used the valid approach of dealing with the host population as the relevant unit, while the impact on the refugees and the internally displaced people from neighbouring districts/counties was excluded.

Contreras et al. (2017) concluded that fewer people seek different housing after a disaster in urban areas; UNV is low in urban centres, but increases with travel distance from the facilities typically located in urban areas. An estimate of the value of UNV should help policymakers decide what facilities, including water, sanitation, basic health care and schools may help people in more rural areas avoid displacement. Similar events may occur in different areas that possess different infrastructure, resources and population sizes and outcomes will vary in each area based on these factors (Ambrosetti et al., 2016). UNV calculations would be of importance with regard to avoiding potential negative outcomes in areas with relatively few resources.

We used GIS in a multidisciplinary approach to address the issues discussed above, applying this technology to public health and refugee registration data to create vulnerability maps for the area under study. This approach was chosen to provide information on where the most vulnerable populations reside in the time of crisis, how many moved from a specific area, what kind of resources would be required and how to plan priority-based interventions. Every part of the world is facing multiple challenges, while resources to address these challenges are limited. These limitations have led governments and international organisations (e.g., the UN agencies) to lobby for financial allocations. For successful outcomes in these undertakings, policymakers must not only be made to fully understand the impending issues but also be sufficiently convinced to act on them. 


\section{Conclusions}

The concept of resilience is related to measurements of preparedness for disasters. Research is needed to measure and predict the capacity of health systems to adapt to humanitarian crises.
There is limited evidence on the impact of preparedness activities with respect to the capacity of health systems to absorb or adjust to crises or disasters. While understanding the importance of these considerable challenges, there is also a need for high-quality evidence with regard to health in the disaster context. It is recom-

Table 4. District hosting refugee populations and the calculated vulnerabilities.

\begin{tabular}{|c|c|c|c|c|c|c|c|c|c|}
\hline $\begin{array}{l}\text { Refugee- } \\
\text { hosting } \\
\text { district }\end{array}$ & $\begin{array}{l}\text { Refugee } \\
\text { camp }\end{array}$ & $\begin{array}{l}\text { Camp } \\
\text { population } \\
\text { (n) }\end{array}$ & $\begin{array}{l}\text { Refugees } \\
\text { (n) }\end{array}$ & $\begin{array}{l}\text { Refugee } \\
\text { families } \\
\text { (n) }\end{array}$ & $\begin{array}{l}\text { Total host } \\
\text { population }\end{array}$ & $\begin{array}{c}\text { Absorption } \\
\text { capacity } \\
\text { vulnerability }\end{array}$ & $\begin{array}{l}\text { Unmet needs } \\
\text { vulnerability }\end{array}$ & $\begin{array}{c}\text { Relative } \\
\text { vulnerability }\end{array}$ & $\begin{array}{c}\text { Total } \\
\text { vulnerability }\end{array}$ \\
\hline Buner & Koga & 11,332 & 11,332 & 1,619 & 937,000 & 0.0120 & 0.0809 & 0.0141 & 0.04 \\
\hline Charsadda & $\begin{array}{l}\text { Adezai } \\
\text { Naguman } \\
\text { Utmanzai } \\
\text { Mundapul }\end{array}$ & $\begin{array}{c}6,260 \\
5,766 \\
5,819 \\
16,996\end{array}$ & 34,841 & 4,977 & 162,6000 & 0.0214 & 0.2486 & 0.0436 & 0.10 \\
\hline Chitral & Kalkatak & 7,658 & 7,658 & 1,094 & 478,000 & 0.0160 & 0.0546 & 0.0095 & 0.03 \\
\hline Di Khan & Pushapul & 10,806 & 10,806 & 1,544 & $1,439,000$ & 0.0075 & 0.0771 & 0.0135 & 0.03 \\
\hline Hangu & $\begin{array}{l}\text { Dalan } \\
\text { Doaba } \\
\text { Kata Karain } \\
\text { Thal } 1\end{array}$ & $\begin{array}{c}12,455 \\
13,192 \\
11,389 \\
9,380\end{array}$ & 46,416 & 6,631 & 53,1000 & 0.0874 & 0.3312 & 0.0581 & 0.16 \\
\hline Haripur & $\begin{array}{l}\text { Basumera camp } 18 \\
\text { Dheenda camp } 13 \\
\text { Padiana camp } 3 \\
\text { Panian camp 6, } \\
\text { Panian camp } 19 \\
\text { Panian camp } 12\end{array}$ & $\begin{array}{r}814,944 \\
22,521 \\
16,144 \\
19,081 \\
17,070 \\
26,754 \\
\end{array}$ & 11,6514 & 16,645 & 986,000 & 0.1181 & 0.3312 & 0.1459 & 0.20 \\
\hline Kohat & $\begin{array}{l}\text { Gamkol } 1 \\
\text { Gamkol } 2 \\
\text { Ghulam Banda } \\
\text { Oblan }\end{array}$ & $\begin{array}{l}23,808 \\
19,372 \\
19,780 \\
15,847\end{array}$ & 78,807 & 11,258 & 949,000 & 0.0830 & 0.5624 & 0.0987 & 0.25 \\
\hline Mardan & $\begin{array}{l}\text { Baghicha camp } \\
\text { Jalala camp } \\
\text { Kagan camp } \\
\text { Zangal Patai }\end{array}$ & $\begin{array}{c}11,218 \\
19,559 \\
5,300 \\
8,548\end{array}$ & 41,304 & 5,901 & $2,369,000$ & 0.0174 & 0.2947 & 0.0517 & 0.12 \\
\hline Lakki Marwat & Gambella & 12,049 & 12,049 & 12,049 & 815,000 & 0.0147 & 0.0860 & 0.1056 & 0.07 \\
\hline Lower Dir & $\begin{array}{l}\text { Chakdara } \\
\text { Taimer } \\
\text { Toor }\end{array}$ & $\begin{array}{c}10,405 \\
15,100 \\
5,064\end{array}$ & 30,569 & 4,367 & $1,244,000$ & 0.0245 & 0.2181 & 0.0382 & 0.09 \\
\hline Manshera & $\begin{array}{l}\text { Barari } \\
\text { Khaki } \\
\text { Ichrian }\end{array}$ & $\begin{array}{l}22,307 \\
22,393 \\
11,923\end{array}$ & 56,623 & 8,089 & $1,700,000$ & 0.0333 & 0.4041 & 0.0709 & 0.17 \\
\hline Nowshera & $\begin{array}{l}\text { Akora } 1 \\
\text { Akora } 3 \\
\text { Akora } 2 \\
\text { Kharirabad Haripur } \\
\text { Turkaman }\end{array}$ & $\begin{array}{c}12,898 \\
16,906 \\
15,005 \\
16,326 \\
5,423 \\
\end{array}$ & 66,558 & 9,508 & $1,394,000$ & 0.0477 & 0.4750 & 0.0833 & 0.20 \\
\hline Peshawar & $\begin{array}{l}\text { Badabair } \\
\text { Baghbanan } \\
\text { Kababian } \\
\text { Khazana } \\
\text { Khurasan } \\
\text { Matani } \\
\text { Mira Kachawri } \\
\text { Zindai }\end{array}$ & $\begin{array}{c}22,664 \\
25,033 \\
16,880 \\
10,846 \\
12,032 \\
9,205 \\
28,974 \\
14,502\end{array}$ & 140,136 & 20,019 & $3,575,000$ & 0.0391 & 1.0000 & 0.1755 & 0.40 \\
\hline Swabi & $\begin{array}{l}\text { Barakai } 1 \\
\text { Barakai } 2 \\
\text { Gandaf }\end{array}$ & $\begin{array}{l}25,628 \\
24,331 \\
22,414\end{array}$ & 72,373 & 10,339 & $1,654,000$ & 0.0437 & 0.5164 & 0.0906 & 0.22 \\
\hline
\end{tabular}




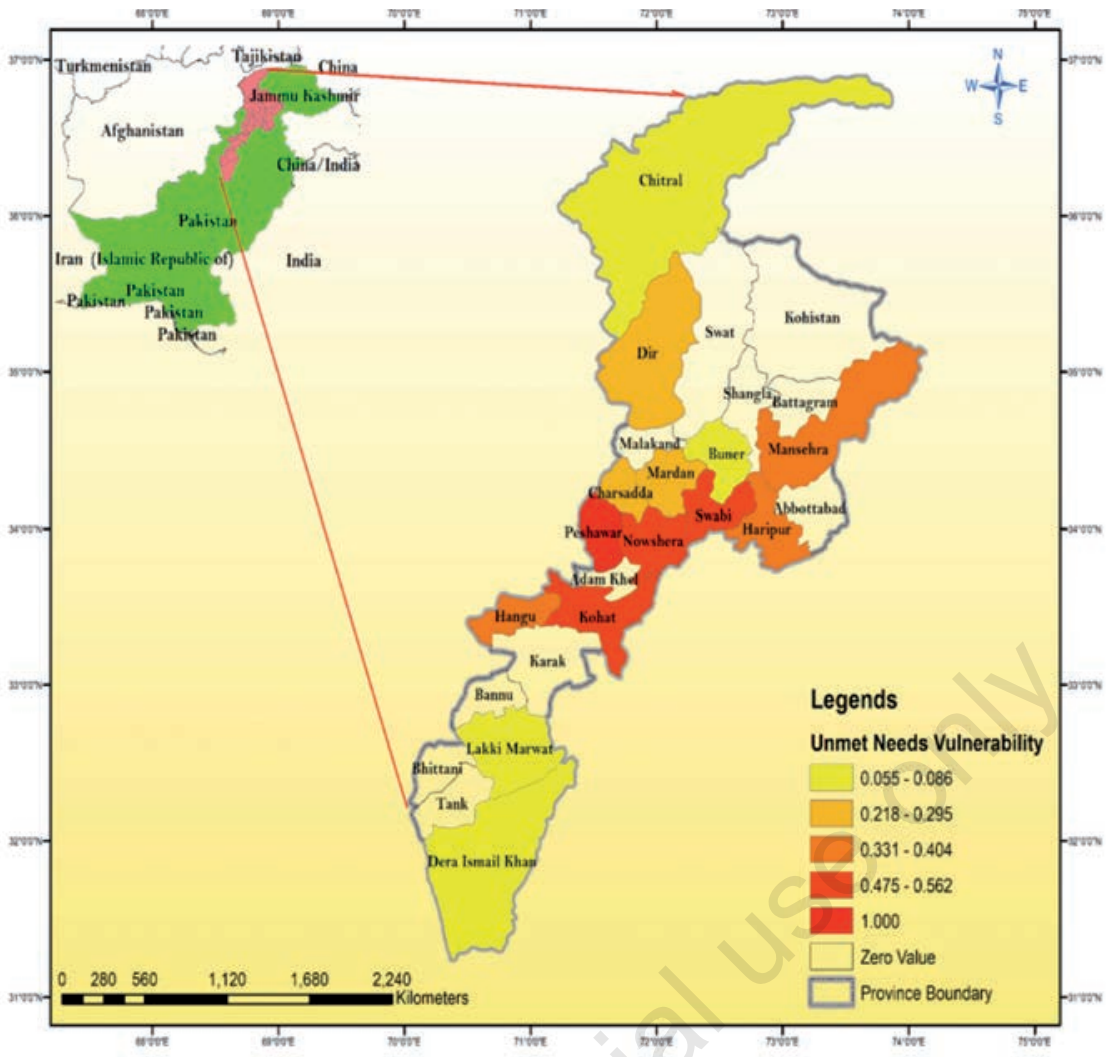

Figure 3. Calculated unmet needs vulnerability at the district level.

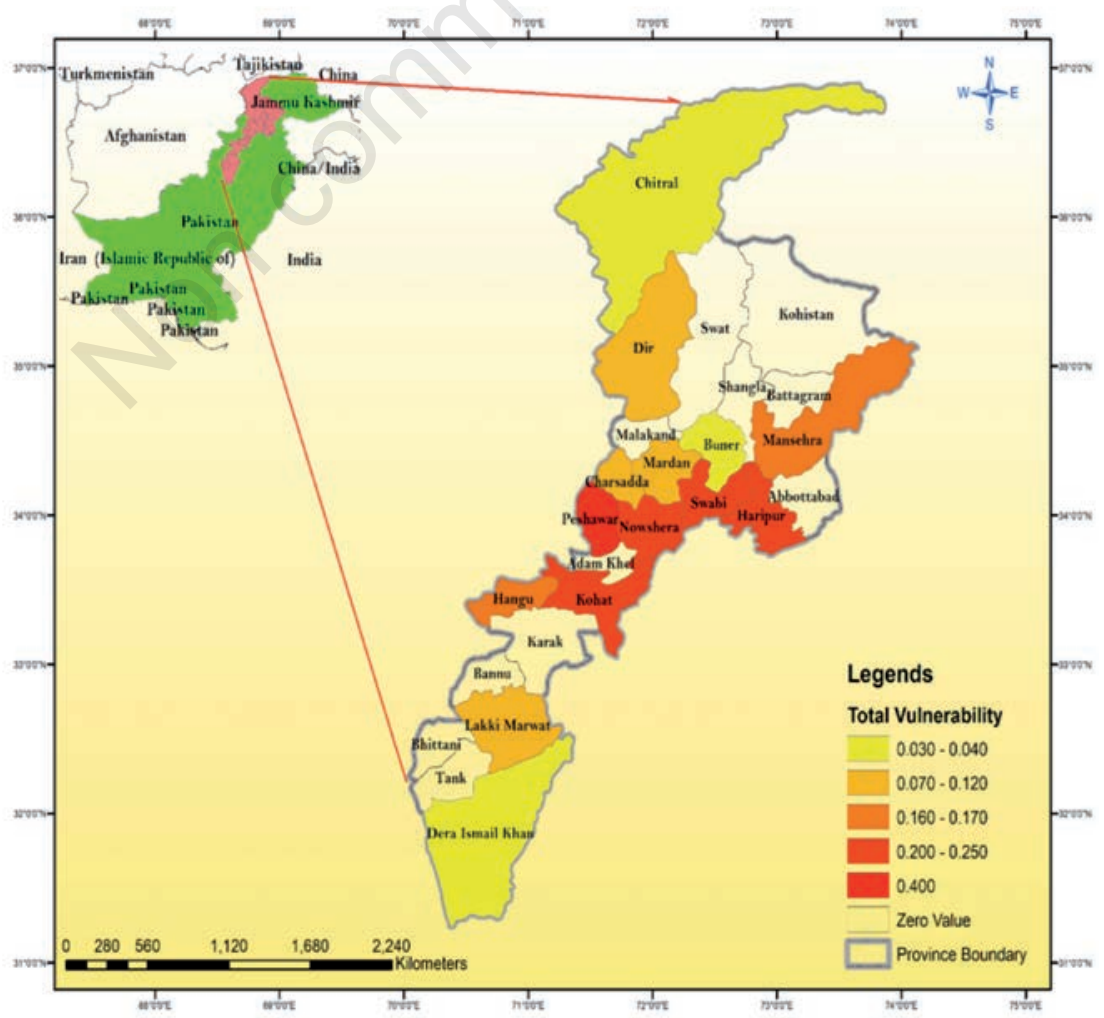

Figure 4. Total vulnerability at the district level. 
mended that organisations managing the issues of refugee and internally displaced people undertake research in public health in this context and plan interventions accordingly.

There is now a pressing need to map and assess all aspects of health risks, hazards and vulnerabilities of the population living in camps, and this study proposes a novel approach to gauge the various forms of vulnerabilities common among displaced populations. It is essential that those living in camps should be reviewed especially against the indicators set by the Millennium Development Goals (MDG) (http://www.un.org/millenniumgoals/) and followed up by the Sustainable Development Goals (SDG) (http://www.un.org/sustainabledevelopment/sustainabledevelopment-goals/). During the last two decades, it has been observed that more and more populations are displaced from their countries of origin by natural and man-made disasters and are living in camps. These numbers are continuously on the rise, and it will, therefore, be impossible to achieve the aims of the SDG if we ignore the risks and vulnerabilities of almost sixty million displaced people.

\section{References}

Adeagbo A, Daramola A, Carim-Sanni A, Akujobi C, Ukpong C, 2016. Effects of natural disasters on social and economic wellbeing: A study in Nigeria. Int J Disast Risk Red 17:1-12.

Ahmad J, Morshed AM, Sadia H, Ahmad A, 2017. Using selected global health indicators to assess public health status of population displaced by natural and man-made disasters. Int $\mathrm{J}$ Disast Risk Red 22:228-37.

Alphen J, Aerts JCJH, 2009. Flood maps in Europe-methods, availability and use. Nat Haz Earth Syst Sci 9:289.

Ambrosetti E, Petrillo ER, 2016. Environmental disasters, migration and displacement. Insights and developments from L'Aquila's case. Environ Sci Pol 56:80-8.

Bonanno GA, Brewin CR, Kaniasty K, Greca AML, 2010. Weighing the costs of disaster: Consequences, risks, and resilience in individuals, families, and communities. Psychol Sci Publ Int 11:1-49.

Boslaugh S, 2007. Secondary data sources for public health: A practical guide. Cambridge University Press, Cambridge, UK.

Byman D, Speakman S, 2016. The Syrian refugee crisis: Bad and worse options. Wash Quart 39:45-60.

Cernea M, 1999. Why economic analysis is essential to resettlement: a sociologist's view. In: Cernea M. (ed.) The economics of involuntary resettlement: questions and challenges. The World Bank, Washington, DC, USA.

Contreras D, Blaschke T, Hodgson ME, 2017. Lack of spatial resilience in a recovery process: Case L'Aquila, Italy. Technol Forecast Soc Change 121:76-88.

Cutter SL, Barnes, Berry M, Burton C, Evans E, Tate E, Webb J, 2008. A place-based model for understanding community resilience to natural disasters. Global Environ Chang 18:598-606.

Cutter SL, Boruff BJ, Shirley WL, 2003. Social Vulnerability to Environmental Hazards. Soc Sci Quart 84:242-61.

de Almeida LQ, Welle T, Birkmann J, 2016. Disaster risk indicators in Brazil: A proposal based on the world risk index. Int $\mathrm{J}$ Disast Risk Re 17:251-72.

Donini A, Monsutti A, Scalettaris G, 2016. Afghans on the move: seeking protection and refuge in Europe. Available from: http://repository.graduateinstitute.ch/record/293919/files/
GMPRS_N17_Donini_Monsutti_Scalettaris_2016.pdf

Ginnetti J, Lavell C, Franck T, 2015. Disaster-related displacement risk: measuring the risk and addressing its drivers. Internal Displacement Monitoring Centre, Geneva, Switzerland. Available from: http://www.internal-displacement.org/assets/ publications/2015/20150312-global-disaster-related-displacement-risk-en.pdf

Greenough PG, Lappi MD, Hsu EB, Fink S, Hsieh YH, Vu A, Heaton C, Kirsch TD, 2008. Burden of disease and health status among Hurricane Katrina-displaced persons in shelters: a population-based cluster sample. Ann Emerg Med 51:426-32.

Haysom S, El Sarraj W, 2013. Sanctuary in the city. ODI, London, UK.

IASC, 2007. Selecting NFIs for shelter. IASC, Geneva, Switzerland.

IDMC, 2014. Pakistan: internal displacement in brief. Available from: http://goo.gl/c4b1Qp

Iram U, Butt MS, 2004. Determinants of household food security: An empirical analysis for Pakistan. Int J Soc Econ 31:753-66.

Kronenfeld DA, 2008. Afghan refugees in Pakistan: not all refugees, not always in Pakistan, not necessarily Afghan? J Refug Stud 21:43-63.

Lim CRB, 2016. Surgery during natural disasters, combat, terrorist attacks, and crisis situations. Springer, Berlin, Germany.

Mannella A, Di Ludovico M, Sabino A, Prota A, Dolce M, Manfredi G, 2017. Analysis of the population assistance and returning home in the reconstruction process of the 2009 L'Aquila earthquake. Sustainability 2017:1395.

Nomura S, Parsons AJ, Hirabayashi M, Kinoshita R, Liao Y, Hodgson S, 2016. Social determinants of mid-to long-term disaster impacts on health: A systematic review. Int J Disast Risk Red 16:53-67.

Pan J, Liu H, Wang X, Xie H, Delamater PL, 2015. Assessing the spatial accessibility of hospital care in Sichuan Province, China. Geospat Health 10:384.

Patankar A, Patwardhan A, 2016. Estimating the uninsured losses due to extreme weather events and implications for informal sector vulnerability: a case study of Mumbai, India. Nat Hazards 80:285-310.

Price R, 2017, July 10. Opinion: See the most vulnerable: see the human landscape. Available from: https://www.devex. $\mathrm{com} /$ news/sponsored/opinion-see-the-most-vulnerable-seethe-human-landscape-90410

Sabates-Wheeler R, Devereux S, Mitchell T, Tanner T, Davies M, Leavy J, 2008. Rural disaster risk-poverty interface. Available from: http://www.ids.ac.uk/publication/rural-disaster-riskpoverty-interface

Sadia H, Iqbal MJ, Ahmad J, Ali A, Ahmad A, 2016. Gender-sensitive public health risks and vulnerabilities' assessment with reference to floods in Pakistan. Int J Disast Risk Re 19:47-56.

Schultz KA, 2017. Mapping interstate territorial conflict: A new data set and applications. J Conflict Resol 61:1565-90.

Sedgh G, Ashoford LS, Hussain R, 2016. Unmet need for contraception in developing countries: examine women's reasons for not using a method. Available from: http://repositorio. gire.org.mx/handle/123456789/2049

Shi L, Stevens GD, 2005. Vulnerability and unmet health care needs: the influence of multiple risk factors. J Gen Intern Med 20:148-54.

Sorensen HT, Sabroe S, Olsen J, 1996. A framework for evaluation of secondary data sources for epidemiological research. Int J Epidemiol 25:435-42. 
Taylor S, 2016. In pursuit of zero: Polio, global health security and the politics of eradication in Peshawar, Pakistan. Geoforum 69:106-16.

UNHCR, 1992. Analytical report of the secretary-general on internally displaced persons. Available from: repository.un.org/bitstream/handle/11176/188685/E_CN.4_1992_23-EN.pdf

UNHCR, 2015. Global trends 2014: world at war. Available from: http://www.refworld.org/docid/558292924.html

UNISDR, 2013. Chair's summary fourth session of the global platform for disaster risk reduction Geneva, 21-23 May 2013. UNISDR, Geneva, Switzerland.
Vecere A, Monteiro R, Ammann WJ, Giovinazzi S, Santos RHM, 2017. Predictive models for post disaster shelter needs assessment. Int J Disast Risk Re 21:44-62.

Weathers A, Minkovitz C, O'Campo P, Diener-West M, 2004. Access to care for children of migratory agricultural workers: factors associated with unmet need for medical care. Pediatrics 113:e276-82.

Wijk-Sijbesma CV, 2016. Gender in community water supply, sanitation, and water resource protection: a guide to methods and techniques. IRC International Water and Sanitation Center, The Hague, The Netherlands. 